Tomasz Gałkowski, C.P.

Wydział Prawa Kanonicznego UKSW

\title{
Papieska Rada ds. Tekstów Prawnych wobec wątpliwości związanych z Listem apostolskim „Mitis Iudex Dominus Iesus”
}

8 grudnia na mocy Listu apostolskiego motu proprio „Mitis Iudex Dominus Iesus"' reformującego kanony Kodeksu Prawa Kanonicznego $^{2}$ weszły w życie nowe przepisy dotyczące spraw o orzeczenie nieważności małżeństwa. Istotną jego częścią są obowiązujące od tego dnia nowe kanony KPK (1671-1691), które zastąpiły dotychczasowe oraz wydane $\mathrm{w}$ formie instrukcji Zasady proceduralne ${ }^{3}$. Te ostatnie stanowią „narzędzia, dzięki którym praca trybunałów mogłaby sprostać potrzebom wiernych, którzy proszą o ustalenie prawdy o istnieniu lub nieistnieniu węzła po rozpadzie ich małżeństwa"4.

Od momentu podpisania Listu przez Franciszka (15.08.2015) i jego promulgacji (8.09.2015) do momentu jego wejścia w życie zorganizowano wiele konferencji i sympozjów, zarówno w Polsce ${ }^{5}$ jak i poza jej

1 Franciszer, Mitis Iudex Dominus Iesus (dalej: MI), w: List apostolski motu proprio „Mitis Iudex Dominus Iesus”, reformujący kanony Kodeksu Prawa Kanonicznego dotyczący spraw o orzeczenie nieważności małżeństwa. List apostolski motu proprio „Mitis et misericors Iesus”, reformujący kanony Kodeksu Kanonów Kościołów Wschodnich dotyczące spraw o orzeczenie nieważności małżeństwa, tekst łacińsko-polski, Tarnów 2015, ss. 5-45.

${ }^{2}$ Dalej: KPK.

3 Dalej: ZP.

4 ZP, Wstęp.

5 Spis takich spotkań podaje W. Góralski, Podsumowanie obrad, w: J. KRAJCZYŃski (red.), Proces matżeński według motu proprio Mitis Iudex Dominus Iesus, Płock 2015, s. 143. 
granicami ${ }^{6}$, które dotyczyły nowych przepisów. Akta będące owocem niektórych spotkań ukazały się drukiem ${ }^{7}$. Z inicjatywy Wydziału Prawa Kanonicznego UPJPII w Krakowie został opublikowany komentarz do nowego dokumentu.

W okresie pomiędzy promulgacją a wejściem w życie MI napływały do Papieskiej Rady ds. Tekstów Prawnych ${ }^{9}$ zapytania dotyczące interpretacji niektórych sformułowań czy też sposobów organizacji działalności trybunałów kościelnych. Na większość z nich Papieska Rada odpowiedziała jeszcze przed wejściem w życie nowych przepisów, na pozostałe już po tym fakcie. Na stronie internetowej Rady znajdujemy 6 takich odpowiedzi, które zawarte są pod wspólnym sformułowaniem: Odpowiedzi szczegółowe (zakładka: Risposte particolari $>$ Procedure per la dichiarazione della nullità matrimoniale ${ }^{10}$ ).

Niektóre z odpowiedzi udzielonych przez Radę zamieszczane są na stronach internetowych Konferencji Biskupów czy stowarzyszeń kanonistycznych. Można się domyślać, że celem nie jest jedynie ułatwienie dostępu do nich, lecz raczej podkreślenie znaczenia odpowiedzi dla poszczególnych Kościołów partykularnych, skoro zamieszczane są one wybiórczo oraz dotyczą sytuacji w nich istniejących. Na oficjalnej stronie internetowej Konferencji Episkopatu Włoch (zakładka: Uffici e servizi $>$ Problemi giuridici $>$ Tribunali $>$ Archivio Notizie $>$ Il motu proprio „Mitis Iudex Dominus Iesus”) znajdujemy jedynie dwie odpowiedzi szczegółowe wydane przez PRTP ${ }^{11}$ oraz jej jeden dokument w formie listu skierowanego do sekretarza generalnego

${ }^{6}$ Celem zapoznania się ze zorganizowanymi w tym celu spotkaniami naukowymi i zapoznania się z wygłoszonymi podczas nich referatami wystarczy prześledzić strony internetowe o tematyce kanonistycznej, jak np. iuscanonicum.it.

7 Por. przypis 5.

8 P. Skonieczny (red.), Praktyczny komentarz do Listu apostolskiego motu proprio Mitis Iudex Dominus Iesus papieża Franciszka, Tarnów 2015.

9 Dalej PRTP.

10 Por. delegumtextibus.va.

11 PRTP, Prot. N. 15157/2015; N. 15201/2015, http://www.chiesacattolica.it/pls/cci_ new_v3/v3_s2ew_consultazione.mostra_pagina?id_pagina=75928 [daty dostępu do wszystkich cytowanych stron internetowych pochodzą z dn. 12.02.2016]. 
tejże Konferencji ${ }^{12}$. Ten ostatni nie znajduje się na stronie internetowej Rady w miejscu, w którym zostały opublikowane pozostałe odpowiedzi w odniesieniu do MI. Nie posiada on co prawda charakteru odpowiedzi, ale doprecyzowuje kwestię, którą PRTP poruszyła w jednym ze swoich poprzednich dokumentów (odpowiedzi szczegółowej $\left.{ }^{13}\right)$. Różnica pomiędzy listem a odpowiedzią szczegółową została podkreślona przez bezpośrednie zaadresowanie listu do sekretarza Konferencji wymienionego z imienia i nazwiska, czego Rada nie czyni w przypadku odpowiedzi szczegółowych. Dwie odpowiedzi wraz z listem zamieszczone na stronie internetowej Konferencji Episkopatu Włoch wskazują, że kwestie w nich poruszane dotyczą sytuacji, która konkretnie istnieje w Kościele we Włoszech.

Dwa dokumenty wydane przez PRTP zostały również opublikowane na włoskiej stronie internetowej poświęconej prawu kanonicznemu. Przytoczone zostały jednak nie jako odpowiedzi szczegółowe, lecz jako noty wyjaśniające ${ }^{14}$. Tylko jeden z nich został umieszczony na stronie internetowej Rady pośród odpowied $z i^{15}$. Drugi nie został zamieszczony w ogóle ${ }^{16}$. Papieska Rada nie klasyfikuje ich pośród not wyjaśniających, które obok wydawania interpretacji autentycznych, deklaracji i rekursów legislacyjnych stanowią jedną z podstawowych form jej aktywności.

Istnieje rozbieżność w stosowaniu nazewnictwa dokumentów wydanych przez PRTP, na co wskazały powyższe przykłady. Ponadto nie wszystkie odpowiedzi udzielone przez Radę zostały zamieszczone na jej oficjalnej stronie, chociaż istnieją na dwóch innych pod różnymi nazwami. Treść odpowiedzi nie zamieszczonej na stronie Rady zostanie omówiona w dalszej części, wraz z próbą wyjaśnienia takiej sytuacji. Poprzedzi ją jednak wyjaśnienie nazw i form dokumentów,

12 PRTP, Prot. N. 15247/2015.

13 Prot. N. 15157/2015.

14 Prot. N. 15157/2015; N. 15201/2015: http://www.iuscanonicum.it/alcuni-primi-chiarimenti-del-pontificio-consiglio-per-i-testi-legislativi-sulla-riforma-del-processo-matrimoniale/.

15 Prot. N. 15201/2015.

16 Prot. N. 15157/2015. 
którymi posługuje się PRTP oraz analiza treści poszczególnych wyjaśnień.

\section{Noty wyjaśniające i deklaracje PRTP}

Dokumenty ogłaszane przez PRTP pod nazwą «nota wyjaśniająca» pojawiły się po raz pierwszy w $1996 \mathrm{r}$. Zawierały one odpowiedzi, które, ze względu na ich zamieszczenie w półroczniku Communicationes ${ }^{17}$ nabierały charakteru publicznych odpowiedzi na kwestie przedstawiane przez dykasterie Kurii Rzymskiej ${ }^{18}$. Rok później pojawiły się ogłoszone drukiem w L'Osservatore Romano i Communicationes odpowiedzi PRTP pod nazwą «deklaracje»" ${ }^{19}$. Obie formy wpisują się w zadania powierzone Radzie przez Jana Pawła II w Konstytucji Apostolskiej Pastor bonus (art. 154-158) z 1998 r. ${ }^{20}$ Nazwy tych dokumentów nie pojawiały się wcześniej, ani nie zostały zawarte w Regulaminie PRTP, który, chociaż zatwierdzony jedynie ad quinquennium $^{21}$, pozostaje nadal źródłem odniesienia dla działania

\footnotetext{
17 PRTP od r. 1993 zaczęła publikować w biuletynie Communicationes kwestie przedstawione Radzie do rozpatrzenia (tzw. questiones submisse). - Por. C. M. PoLVANI, Authentic interpretation in canon law. Reflections on a distinctively canonical institution, Roma 1999, s. 305.

18 Notae explicativae, Communicationes 28 (1996) 2, ss. 177-186.

19 Dichiarazione, Communicationes 29 (1997) 1, ss. 17-18. W przypisie na s. 17 zawarte jest odniesienie do wcześniejszej publikacji na łamach L’Osservatore Romano. 20 Jan Paweł II, Pastor bonus, 28.06.1998, tekst łac.-pol. w: P. MAJer (red.), Kodeks Prawa Kanonicznego. Komentarz, Kraków 2011, ss. 1397-1465 (dalej: PB).

21 W PB art. 38 zostało zarządzone, by każda dykasteria posiadała własny Regulamin, w którym powinny być określone normy dotyczące porządku i sposobu załatwiania spraw. Regulamin PRTP został zatwierdzony przez Sekretarza Stanu Stolicy Apostolskiej 4.06.1994 r. po tym, jak wcześniej Jan Paweł II zatwierdził ad quinquennium Regulamin Kurii Rzymskiej (4.02.1992). Ostateczna aprobata, po wcześniejszych zmianach i dostosowaniach, nastąpiła 15.04.1999 r. Regulamin Kurii Rzymskiej wszedł w życie 1 lipca.
} 
Rady. Byłoby dobrze, by tekst ten został zamieszczony na jej stronie oficjalnej ${ }^{22}$.

Do uprawnień przysługujących Radzie należą działania bezpośrednio lub pośrednio związane $\mathrm{z}$ funkcją interpretacji prawa Kościoła katolickiego (art. 154). W art. 155-158 PB zostały unormowane poszczególne jej zadania: a) dokonywanie interpretacji autentycznej ustaw powszechnych; b) pomoc techniczno-prawna dykasteriom Kurii Rzymskiej (opinia lub ekspertyza w sprawie zgodności wydawanych przez nie ogólnych dekretów wykonawczych i instrukcji z obowiązującymi przepisami prawa oraz ich redakcji w odpowiedniej formie); c) sprawdzanie pod względem prawnym (recognitio) dekretów ogólnych wydawanych przez zespoły biskupów; d) rozstrzyganie o zgodności lub jej braku ustaw partykularnych i dekretów ogólnych wydawanych przez ustawodawców niższych od władzy najwyższej z prawem powszechnym Kościoła. Powyższe zadania zawarte w $\mathrm{PB}$ można sprowadzić do dwóch podstawowych aktywności Rady: 1) działalność interpretacyjna (PB 154-155); 2) działalność polegająca na trosce o zagwarantowanie właściwej aplikacji obowiązujących norm prawnych (PB 156-158).

PRTP nie poprzestaje jedynie na zadaniach wyznaczonych jej przez Konstytucję PB. Od momentu jej wejścia w życie upłynęło ponad 25 lat. W tym czasie Rada, wraz z doskonaleniem praktycznych form realizacji powierzonych jej zadań, rozwijała także nowe pola swej działalności. Jak podaje oficjalna strona internetowa Rady do nowych form jej aktywności należą: a) składanie propozycji legislacyjnych najwyższemu prawodawcy kościelnemu w przypadku luk prawnych czy przestarzałych (przeżytych) norm obowiązujących w Kościele katolickim kodeksów lub pozakodeksowych norm

\footnotetext{
22 Jeszcze na przełomie 2013/14 r. M. Ganarin w swojej rozprawie doktorskiej stwierdzał wyraźnie, po przeanalizowaniu sposobu działania PRTP, że normy Regulaminu z 1994 r. pozostają nadal podstawowym źródłem odniesienia dla sposobu funkcjonowania Rady. - Por. M. GANARIN, L'interpretazione autentica delle leggi universali della Chiesa. La competenza del Pontificio Consiglio per i testi legislativi, Milano 2013/14, s. 116. Tekst rozprawy doktorskiej: https://air.unimi.it/retrieve/ handle/2434/254241/348858/phd_unimi_R09221.pdf.
} 
powszechnie obowiązujących; b) promowanie znajomości i praktyki prawa kanonicznego wykorzystując $\mathrm{w}$ tym celu spotkania $\mathrm{z}$ biskupami, zwłaszcza podczas ich wizyt ad limina, poprzez kontakty utrzymywane z ośrodkami naukowymi prawa kanonicznego (instytucje akademickie czy stowarzyszenia kanonistów) oraz przez podejmowanie własnych inicjatyw naukowych (organizowanie sympozjów, konferencji naukowych, własne publikacje: czasopisma i książki); c) podejmowanie zadań powierzonych Radzie na mocy specjalnego zlecenia (mandatum) najwyższego prawodawcy (np. wydanie Instrukcji Dignitas connubii 25.01.2005 r. $)^{23}$.

Analiza treściowa deklaracji i not wyjaśniających wskazuje wyraźnie, że wpisują się one w podstawową działalność Rady związaną z pośrednią interpretacją obowiązujących tekstów prawnych Kościoła katolickiego w celu ich właściwej aplikacji. Nie wszystkie zapytania kierowane do Rady wymagają interpretacji zgodnie z obowiązującymi regułami interpretacyjnymi (kan. 17). Kwestie dotyczące jedynie właściwego zastosowania prawa przekazywane są zazwyczaj kompetentnej ze względu na przedmiot (ratione materiae) dykasterii wraz z dołączoną opinią Rady, jeśli konieczność tego wymaga. O takim przekazaniu zostaje powiadomiony również ten, kto zwrócił się z petycją ${ }^{24}$.

\footnotetext{
${ }^{23}$ Szerzej poszczególne nowe formy działalności PRTP zostały zaprezentowane w Profilu Rady na oficjalnej stronie Stolicy Apostolskiej: http://www. vatican.va/roman_curia/pontifical_councils/intrptxt/documents/rc_pc_ intrptxt_pro_20061122_it.html.

24 Por. Regulamin Rady (dalej RR), art. 17. Lukę z powodu braku opublikowanego RR uzupełnia Julián Herranz Casado (były przewodniczący Rady) podając obszerne fragmenty Regulaminu w swoich opracowaniach, do których nawiązują komentatorzy zajmujący się problematyką interpretacji. Por. L'interpretazione autentica: Il Pontificio Consiglio per L'interpretazione dei Testi Legislativi della Chiesa, w: IL diritto della Chiesa. Interpretazione e prassi, Studi Giuridici XLI, Città del Vaticano 1996, ss. 78-81; Il Pontificio Consiglio per i Testi Legislativi: natura, competenze e metodo, http://www.vatican.va/roman_curia/pontifical_councils/intrptxt/documents/ rc_pc_intrptxt_doc_20040809_pc-intrptxt_it.html. Tłumaczenie Regulaminu na język polski znajduje się w: A. KACzor, Papieska Rada do spraw Interpretacji Tekstów Prawnych, w: A. Dęвıński, E. Szczot (red.), Plenitudo legis dilectio. Księga
} 
Zadaniem PRTP jest interpretacja prawa. W art. 154 PB zostało zaznaczone, że interpretacja dotyczy przede (praesertim) wszystkim ustaw kościelnych. W tym sformułowaniu została wyrażona myśl, że nie tylko ustawy kościelne mogą być przedmiotem interpretacji. Są nim również wszelkie inne akty prawne istniejące w Kościele katolickim. Interpretacji autentycznej wymaga tekst aktu normatywnego, który zawiera w sobie wątpliwość prawną (dubium iuris). W sytuacji, jak czytamy na Profilu Rady, w której taka wątpliwość się nie pojawia, Rada może dokonać miarodajnego wyjaśnienia znaczenia obowiązującej normy prawnej stosując kryteria interpretacyjne podane w kan. 17 KPK. Ponadto dla jasności w tekście odpowiedzi powinno być zaznaczone pozbawienie wyjaśnienia formy interpretacji autentycznej. Dalej czytamy, że takie wyjaśnienia mogą przyjąć także nazwy: «deklaracja» czy «nota wyjaśniająca». Ten sposób dokonywania wyjaśnień został unormowany w art. $18 \mathrm{RR}$. Brak w nim jednak określeń technicznych nazw dokumentów, za pomocą których wyjaśnienia są przedstawiane. Czytamy w nim jedynie, że pojawienie się wątpliwości wynikającej z niewłaściwej interpretacji prawa czy mającej charakter subiektywny w sytuacji, w której tekst prawny sam w sobie jest jasny powoduje udzielenie odpowiedzi przez przewodniczącego Rady w sposób oficjalny ${ }^{25}$, który powszechnie jest rozumiany jako forma pisemna ${ }^{26}$. Odpowiedź nie wymaga promulgacji oraz wcześniejszego zatwierdzenia przez najwyższego prawodawcę kościelnego. Wydaje się bardzo prawdopodobne, że wymóg oficjalności zawarty w tekście RR sprowokował powstanie wyżej wymienionych dwóch rodzajów odpowiedzi, którymi posługuje się Rada udzielając

pamiątkowa dedykowana prof. dr. hab. Bronisławowi W. Zubertowi OFM z okazji 65. rocznicy urodzin, Lublin 2000, ss. 414-418.

${ }^{25}$ Odpowiedź przewodniczącego Rady poprzedzona jest wysłuchaniem opinii sekretarza, „a jeśli wymaga tego dana kwestia, opinii konsylium i konsultorów, w zależności od sprawy, jaką się bada. W tekście odpowiedzi będzie zaznaczone, że nie jest to interpretacja autentyczna" (RR, art. 18).

26 C. M. Polvani, Authentic interpretation in canon law..., dz. cyt., s. 303. 
wyjaśnień nieprzyjmujących formy interpretacji autentycznej ${ }^{27}$. Tym samym Rada nadała oficjalnym wypowiedziom charakter publiczny dając możliwość zapoznania się z nimi wszystkim zainteresowanym oraz wskazując na ich wartość jako punkt odniesienia dla właściwego rozumienia prawa ${ }^{28}$. Publikacja świadczy, że odpowiedź będzie posiadała znaczący wpływ na wszelkie następne decyzje organów stosujących prawo. Pozostanie nadal wypowiedzią o charakter opinii, ale ta nabierze charakteru generalności i stanie się opiniotwórczą.

Powyższe uwagi pozwalają na ukazanie różnic formalnych (forma językowa oraz wymogi dotyczące sposobu ogłoszenia) pomiędzy interpretacją autentyczną i wyjaśnieniem. Tym samym wyodrębniają elementy ułatwiające bliższe określenie form, w których wyjaśnienia są dokonywane (deklaracje, noty wyjaśniające). W wyjątkowych przypadkach może się zdarzyć, że oficjalna, pisemna forma udzielenia wyjaśnienia w oparciu o obowiązujące normy ${ }^{29}$ na mocy decyzji najwyższego prawodawcy nie jest publikowana. Racje takiej decyzji wynikają albo z przedmiotu interpretacji albo dotyczą adresata odpowiedzi udzielonej przez PRTP $^{30}$. Nie jest to jednak zbytnim utrudnieniem dla określenia charakterystycznych cech deklaracji czy noty, gdyż w przeważającej większości są one publikowane.

Różnice w formie wydawania przez PRTP interpretacji autentycznych dokonywanych w formie ustawy (per modum legis) a deklaracjami czy notami wyjaśniającymi przedstawiają się następująco:

\footnotetext{
27 RR został zatwierdzony w 1994 r. Nazwy rodzajów odpowiedzi Rady pojawiły się kilka lat później (nota 1996 r.; deklaracja 1997 r.).

28 J. Otaduy, Sobre las "Notas Explicativas" del Consejo Pontifici para la interpretación de los textos legislativos de la ley canónica, Ius Ecclesiae 9 (1979), s. 639.

29 Posługuję się sformułowaniem «obowiązujące normy» odróżniając je od «obowiązujących przepisów». W drugim przypadku chodzi bowiem o stwierdzenie istnienia obowiązujących przepisów, z których w procesie interpretacji należy odkodować zawarte w nich normy. W pierwszym natomiast mam na myśli gotowe normy, które wymagają zastosowania.

30 J. H. Casado, L'interpretazione autentica: Il Pontificio Consiglio per L'interpretazione dei Testi Legislativi della Chiesa, art. cyt., s. 80.
} 
a) interpretacja autentyczna występuje jako «odpowiedź». Rada wyraża ją jednak pod podwójnym sformułowaniem jako responsum lub responsio lub całkowicie pomijając tę nazwę. Interpretacja jako odpowiedź na wątpliwość wskazuje na znaczenie wybranej przez Radę formy literackiej, ale nie uwzględnia jeszcze znaczenia samej decyzji ${ }^{31}$. Pominięcie nagłówka wskazuje, że działalność Rady nie ogranicza się jedynie do udzielania odpowiedzi. Ona sama z własnej inicjatywy może dokonywać interpretacji autentycznej, która tym samym nie będzie odpowiedzią.

Pojęcie «noty wyjaśniającej» (nota explicativa) pojawiło się w drugim zeszycie Communicationes z 1996 r., pod którym to tytułem zostały wymienione dwa dokumenty wydane w 1996 r.: „Assoluzione generale senza previa confessione individuale”32 oraz „Obbligo del vescovo di risiedere in diocesi" ${ }^{33}$. Aczkolwiek oba dokumenty zostały opublikowane jako noty wyjaśniające, to w dalszej części czytamy, że są to odpowiedzi na pytania skierowane do konkretnie pytających podmiotów. Po raz pierwszy ze sformułowaniem «nota» spotykamy się w dokumencie Rady „Sulla scomunica per scisma in cui incorrono gli aderenti al movimento del Vescovo Marcel Lefebvre" ${ }^{\text {" }}$. We wcześniejszym dokumencie z 1994 r. używane jest sformułowanie «wyjaśnienia» (chiarimenti) ${ }^{35}$. W kolejnych dokumentach PRTP umieszczonych na jej stronie internetowej pod wspólną nazwą «Noty» i wydanych po 1996 r. napotykamy na sformułowania: «odpowiedź» ${ }^{36}$,

\footnotetext{
31 A. Kaczor, Papieska Rada Tekstów Prawnych i interpretacje autentyczne, Kościół i Prawo 2 (2013) nr 2, s. 155.

32 Prot. N. 5309/96.

33 Prot. N. 5125/96.

34 Communicationes 29 (1997), ss. 239-243.

35 Chiarimenti circa il valore vincolante dell'art. 66 del Direttorio per il ministero e la vita dei presbiteri, Communicationes 27 (1995), ss. 192-194.

${ }^{36} \mathrm{~Np}$. La partecipazione in modo stabile dei Superiori Religiosi alla Conferenza Episcopale, Communicationes 29 (1997), ss. 236-238.
} 
«nota wyjaśniająca» ${ }^{37}$, «wyjaśnienia ${ }^{38}$. Pośród not są również takie dokumenty, które nie zawierają w swojej treści odniesienia do żadnej nazwy ${ }^{39}$.

Pod nazwą «deklaracja», która pojawiła się w Communicationes po raz pierwszy w $1997 \mathrm{r}$. na stronie internetowej PRTP znajdują się trzy dokumenty począwszy od ich wydania w tymże roku, z których tylko jeden zawiera w swoim tytule powyższe sformułowanie ${ }^{40}$. W sytuacji, w której Rada nie używa w nazwie dokumentu sformułowania «deklaracja», stwierdza w treści dokumentu, że coś deklaruje ${ }^{41}$.

b) Noty wyjaśniające, podobnie jak interpretacje autentyczne mogą występować jako odpowiedzi na konkretne zapytania skierowane do PRTP przez różne podmioty kościelne. Odpowiedź dana przez Radę, w której używa ona sformułowania «odpowiedź» nie jest elementem odróżniającym interpretację autentyczną od not wyjaśniających. Gdy Rada posługuje się innymi sformułowaniami (nota wyjaśniająca, wyjaśnienia) mamy najczęściej do czynienia z odpowiedziami na konkretne zapytania. Także interpretacja autentyczna niekoniecznie musi zawierać sformułowanie «responsum».

\footnotetext{
$37 \mathrm{~Np}$. Sulla scomunica per scisma in cui incorrono gli aderenti al movimento del Vescovo Marcel Lefebvre, Communicationes 29 (1997), ss. 239-243. Dwa dokumenty zawierają ponadto w samym tytule sformułowanie «nota wyjaśniająca»: Nota explicativa quoad can. 1 CCEO, Communicationes 43 (2011), ss. 315-316; Nota explicativa quoad pondus canonicum divortii orthodoxi, Communicationes 44 (2012), ss. 357-359. 38 Chiarimenti circa l'applicazione del can. 223 \$2 CIC, Communicationes 44 (2010), ss. 280-281.

$39 \mathrm{~Np}$. La funzione dell'autorità ecclesiastica sui beni ecclesiastici, Communicationes 36 (2004), ss. 24-32.

40 Dichiarazione sulla retta applicazione del canone 1382 del Codice di Diritto Canonico [http://www.delegumtextibus.va/content/testilegislativi/it/attivita/dichiarazioni/retta-applicazione-del-can-1382-del-cic.html].

${ }^{41}$ Circa la celebrazione dei sacramenti da parte dei sacerdoti che hanno attentato il matrimonio, Communicationes 29 (1997), ss. 17-18; Circa l'ammissibilità alla santa comunione dei divorzati risposati, Communicationes 32 (2000), ss. 159-162.
} 
Elementem odróżniającym interpretację autentyczną od not wyjaśniających w aspekcie zewnętrznym jest różna ich forma językowa. Interpretacja autentyczna jest odpowiedzią, w której Rada dokonuje wyboru. Zaznaczone jest to w tekście poprzez użycie specyficznych łacińskich sformułowań: utrum, a następnie an, aut, et jak również ponownie utrum. Odpowiedź jest dana na każde z postawionych pytań w formie krótkich sformułowań: affirmative lub positive. Tej specyficznej formy językowej nie posiadają ani noty wyjaśniające, ani deklaracje. Ponadto interpretacje autentyczne nie zawierają żadnych wyjaśnień w przeciwieństwie do not czy deklaracji ${ }^{42}$, które same w sobie są wprost wyjaśnieniami lub stwierdzeniami wyjaśniającymi i precyzującymi tekst prawny w kontekście jego aplikacji.

c) Interpretacje autentyczne nie określają, do kogo są skierowane. Nie jest również podany w nich sam pytający. W przypadku not wyjaśniających mamy do czynienia z ogólnymi sformułowaniami wskazującymi, że zapytanie czy prośba o wyjaśnienie pochodzą od jakiejś dykasterii czy innej osoby wskazanej poprzez określenie urzędu, który zajmuje bez określenia miejsca jego sprawowania. W przeciwnym razie prowadziłoby to do identyfikacji osoby. Taka praktyka, którą można odczytać z samych dokumentów, jest powszechna. Zdarzają się jednak wyjątki, jak w przypadku cytowanej już noty wyjaśniającej „Sulla scomunica per scisma...”, w której Rada kieruje swoje wyjaśnienie za pośrednictwem Kongregacji Biskupów do konkretnego biskupa w Szwajcarii podanego z imienia i nazwiska. Istnieją również noty, które nie mają adresata ${ }^{43}$.

Poprzez praktykę braku zamieszczenia w analizowanych dokumentach adresata wypowiedzi PRTP podkreśla powszechność obowiązywania jej decyzji. W przypadku interpretacji autentycznych

\footnotetext{
42 Zdarzają się jednak wyjątki. Takim przykładem jest interpretacja autentyczna dotycząca słowa abicere zawartego w kan. 1367 KPK i 1442 KKKW, do której w odrębnym dokumencie dołączono wyjaśnienie podjętej decyzji. - Por. Communicationes 31 (1999), s. 42-49.

43 Elementi per configurare l'ambito di responsabilità canonica del Vescovo diocesano nei riguardi dei presbiteri incardinati nella propria diocesi e che esercitano nella medesima il loro ministero, Communicationes 36 (2004), ss. 33-38.
} 
jest zewnętrzną wskazówką ich charakteru ustawowego. Adresatami interpretacji autentycznej są bowiem wszyscy ci, których ustawa dotyczy. W przypadku not i deklaracji brak zaznaczenia konkretnego adresata wskazuje na pewną jednoznaczność i stabilność samego prawa odgrywającą podstawową rolę w procesie jego stosowania i przestrzegania, na który zwraca się uwagę osobie proszącej o wyjaśnienie. Podobne motywy decydują o tym, że nie jest również zamieszczany adres adresata. W interpretacjach autentycznych oraz deklaracjach brak jest również początkowego powitania, jak to ma miejsce w przypadku niektórych not.

d) Wszystkie trzy formy omawianych dokumentów podpisane są przez przewodniczącego i sekretarza PRTP.

e) Interpretacje autentyczne dokonywane przez PRTP wymagają promulgacji zgodnie $\mathrm{z}$ obowiązującymi przepisami prawa (kan. 8 $\S 1$ ). Wynika to z charakteru ustawowego interpretacji (per modum legis). Noty i deklaracje w większości przypadków są publikowane. Z zamieszczonych na stronie internetowej PRTP not wyjaśniających wynika, że są one publikowane w Communicationes, natomiast deklaracje zarówno w tym periodyku, jak i w L'Osservatore Romano. Szersze ich rozpowszechnienie sprzyja większej możliwości zapoznania się z nimi, a jednocześnie wskazuje na powszechność i zgodę co do ich treści. Trudno jest na podstawie dostępnego materiału stwierdzić, czy jest to praktyka obowiązująca czy raczej wybór dokonany z wielu możliwości. Można mówić jedynie o pewnej obranej i raczej stałej formie publikacji. Z pewnością jednak Rada nie jest do niej ograniczona. Dotyczy to również interpretacji autentycznych, które ukazują się w Communicationes, jak również w L'Osservatore Romano.

Na podstawie formy zewnętrznej dokumentów o wiele łatwiej jest odróżnić interpretacje autentyczne od not wyjaśniających i deklaracji, niż dokonać rozróżnienia pomiędzy tymi dwiema ostatnimi. Pierwsza różnica wynika przede wszystkim z charakteru ustawowego interpretacji autentycznej i specyficznej dla niej formy językowej oraz konieczności jej promulgacji. Noty i deklaracje będące również oficjalną formą udzielania odpowiedzi czy wyjaśnień, ale nie posiadające 
vim legis, nie są promulgowane, lecz jedynie publikowane, i to nie w każdym przypadku.

Analiza treści omawianych dokumentów uwidacznia precyzyjnie różnice pomiędzy interpretacją autentyczną a notą i deklaracją. Ponadto $\mathrm{w}$ tekście odpowiedzi ma być zaznaczone, że nie są one interpretacją autentyczną ${ }^{44}$, która wynika $z$ wątpliwości prawnej sprowokowanej przez tekst normatywny. Podstawą odróżnienia interpretacji autentycznej od każdej innej dokonywanej przez PRTP jest natura wątpliwości: prawna czy faktyczna. O niej decyduje sama Rada podejmując się jednej z przewidzianych możliwości działania: albo interpretacja autentyczna albo nota czy deklaracja.

Czym zatem jest nota, a czym deklaracja?; czym różnią się między sobą? Są to pytania, które wymagają odpowiedzi, by można było się ustosunkować do kwestii przedstawionych na początku opracowania, dotyczących zamiennego stosowania tych nazw i analizy treści tytułu niniejszego opracowania.

Różnica pomiędzy notą a deklaracją, o ile nie jest użyta ta nazwa w treści dokumentu, uwidacznia się przede wszystkim poprzez miejsce publikacji. Może to być jednak czasami mylące w rozpoznaniu charakteru danego dokumentu. Nie istnieje zakaz ich publikacji w innych miejscach, ani nakaz publikacji w jakimś jednym i konkretnym. Nie widzę powodu, dla którego PRTP nie mogłaby wyraźnie w nagłówku, jak to jest w kilku przypadkach, jasno określić rodzaju dokumentu, który wydaje.

Cechą charakterystyczną not wyjaśniających $\mathrm{z}$ formalnego i materialnego punktu widzenia jest to, że skierowane są one do konkretnych adresatów, w tym na pierwszym miejscu dykasterii Kurii Rzymskiej, do których dyspozycji Rada pozostaje ${ }^{45}$. Nasuwa się zatem wniosek, że są wydawane jako odpowiedzi na zapytania, z jakimi się one zwracają do PRTP. Odpowiedzi Rady dotyczą kwestii stosowania prawa, gdy ono samo w sobie jest jasne i pewne, o czym świadczy dotychczasowa praktyka. Na dowód istnienia tego rodzaju wątpliwości (dubia mere

44 RR, art. 18.

45 PB, art. 156. 
applicativa), a nie wątpliwości prawnej wymagającej interpretacji autentycznej, Rada w odpowiedziach odwołuje się np. do stałego nauczania najwyższego prawodawcy, który wielokrotnie przypominał obowiązujące normy, do historii i natury instytucji prawnych, czy też wyraźnie stwierdzając, że wątpliwość dotyczy zastosowania prawa.

Zapytania kierowane do Rady, które nie wymagają interpretacji autentycznej, dotyczą właściwego zastosowania prawa i na ogół w takich przypadkach powinny być przekazywane dykasterii posiadającej władzę wykonawczą i kompetentnej ze względu na przedmiot wraz, jeśli to konieczne, $\mathrm{z}$ opinią Rady, która posiada walor ekspertyzy technicznej ${ }^{46}$. $Z$ tego powodu noty wyjaśniające mogą być uważane również za opinie i tak nazywane. Mogą zaistnieć sytuacje, w których osoba pytająca zwraca się do konkretnej dykasterii, a ta następnie prosi Radę o wyjaśnienie wątpliwości. W tych dwóch przypadkach, gdy akt normatywny jest jasny sam w sobie, odpowiedź udzielana jest przez Radę w formie wyjaśnienia w sposób oficjalny ${ }^{47}$.

Na podstawie dwóch artykułów RR 17 i 18 nota wyjaśniająca ukazuje się jako opinia lub wyjaśnienie Rady zaadresowane do konkretnego podmiotu ze względu na wcześniej skierowane do niej zapytanie. Dołączona opinia, jak również użyte w nazwie dokumentu sformułowanie «wyjaśniająca» świadczy, że mamy do czynienia tak z opinią, jak i z wyjaśnieniem. Opinia Rady nie posiada jednak mocy wiążącej dla dykasterii ${ }^{48}$. Pozostaje zawsze jedynie opinią. Dykasteria pozostaje niezależna w jej kompetencjach i wolna w podejmowaniu decyzji.

Cechą charakterystyczną noty wyjaśniającej wynikającą z jej treści jest to, że jest to odpowiedź w formie opinii na pytanie skierowane przez dykasterie Kurii Rzymskiej lub przez inne podmioty bezpośrednio lub za pośrednictwem dykasterii do PRTP dotycząca sytuacji,

\footnotetext{
46 RR, art. 17. Por. np. Notę Circa i casi in cui la cura pastorale di più parrocchie è affidata ad un solo parroco, Communicationes 30 (1998), s. 28-29. Wraz z notą została opublikowana opinia Rady, ss. 30-32.

47 RR, art. 18.

48 Pewność prawa wymaga, by w tej sytuacji nie dochodziło do ewentualnie możliwego konfliktu pomiędzy opinią Rady a decyzją wykonawczą podjętą przez odpowiedni organ.
} 
w jakiej znalazł się podmiot postawiony wobec konieczności stosowania norm prawnych lub wyjaśnienia wątpliwej sytuacji. W przypadku not wyjaśniających mamy zatem do czynienia $\mathrm{z}$ podmiotem pytającym oraz z przewidywalną lub konieczną sytuacją stosowania prawa, przed którą podmiot ów się znajduje i nie jest pewny co do prawidłowości swoich poczynań.

Deklaracje, co może prowadzić do ich mylenia z notami, są również wydawane celem właściwego zastosowania przepisów prawnych przy określonych założeniach i w konkretnych okolicznościach ${ }^{49}$. W przeciwieństwie do not wyjaśniających deklaracje nie są odpowiedzią na konkretne zapytania podmiotów, które stoją wobec decyzji konieczności podjęcia odpowiednich zachowań gdy pojawia się po ich stronie wątpliwość dotycząca zastosowania prawa. Zamieszczone na stronie internetowej PRTP deklaracje są podstawą do stwierdzenia, że motywem ich wydania jest istniejąca praktyka nieprzestrzegania prawa i niewłaściwego stosowania (sakra biskupia bez mandatu papieskiego) czy pojawiające się opinie znawców i interpretacje prawa sprzeczne z obowiązującymi normami z punktu widzenia Rady (dopuszczenie do komunii św. rozwodników, którzy zawarli nowe związki cywilne) wprowadzające w błąd wiernych Kościoła. Obie sytuacje dotyczą stosowania prawa. Rada wydaje deklaracje gdy jest o to proszona ${ }^{50}$ lub $\mathrm{z}$ własnej inicjatywy, a w niektórych przypadkach również w porozumieniu $\mathrm{z}$ innymi dykasteriami. W wydanej deklaracji Rada najpierw przedstawia zaistniałą praktykę, a następnie wydaje swoją opinię dotyczącą prawidłowego sposobu stosowania prawa. Opis sytuacji jest jednocześnie podaniem motywu wydania deklaracji. Deklaracja nie jest skierowana do konkretnego adresata. Poprzez publikację

\footnotetext{
49 C. M. Polvani, Authentic interpretation in canon law. Reflections on a distinctively canonical institution..., dz. cyt., s. 308.

50 Tak jest w przypadku deklaracji Circa la celebrazione dei sacramenti da parte di sacerdoti che hanno attentato il matrimonio, która jest odpowiedzią na skierowane zapytanie do PRTP. Pozostałe dwie (Circa l'ammissibilità alla Santa Comunione dei divorziati risposati; Sulla retta applicazione del canone 1382 del Codice di Diritto Canonico) opublikowane na stronie internetowej Rady nie odnoszą się w ich tekście do skierowanych pytań z wątpliwościami.
} 
Rada chce przypomnieć o treści powszechnie obowiązującej normy prawnej, która wymaga przestrzegania. Deklarując (stwierdzając z przekonaniem, stanowczością) Rada przypomina obowiązujące przepisy oraz właściwą ich interpretację i uwrażliwia na konieczność ich prawidłowego stosowania. Obowiązywalność normy jest bowiem racją jej istnienia. Wymusza jej przestrzeganie i stosowanie.

Wyjaśnienia dokonane przez Radę za pomocą deklaracji są oświadczeniami jej oficjalnego stanowiska. Są stwierdzeniem, zadeklarowaniem istniejącej i zobowiązującej sytuacji, w czym z pewnością zbliżają się do określenia deklaracji w znaczeniu używanym w kan. 1335 w jego relacji do kan. 1394.

Bliższa charakterystyka not wyjaśniających w odróżnieniu ich od deklaracji ${ }^{51}$ pozwala na zestawienie not i odpowiedzi szczegółowych. Obie formy wyjaśnień udzielonych przez PRTP są odpowiedziami, które mogą być mylone i błędnie nazywane nawet wtedy, gdy jasno zostały określone przez PRTP ${ }^{52}$.

\section{Odpowiedzi szczegółowe}

Oficjalny Profil PRTP zamieszczony na watykańskiej stronie internetowej wskazuje na dwa rodzaje dokumentów, którymi posługuje się Rada wyjaśniając wątpliwości dotyczące stosowania prawa. Są to przedstawione powyżej deklaracje i noty wyjaśniające. Na swojej stronie internetowej Rada opublikowała również sześć odpowiedzi na szczegółowe kwestie dotyczące prawidłowego stosowania norm zawartych w MI. Na stronie Konferencji Episkopatu Włoch została zamieszczona jeszcze jedna odpowiedź Rady, której nie ma na jej stronie

\footnotetext{
51 Istnieją noty, w których PRTP nie odwołuje się do przedstawionych jej zapytań. W swej formie zbliżają się do deklaracji, co może być przedmiotem nieporozumień. Przykładem jest nota wyjaśniająca Elementi per configurare l’ambito di responsabilità canonica del Vescovo diocesano nei riguardi dei presbiteri incardinati nella propria diocesi e che esercitano nella medesima il loro ministero.

52 Taka sytuacja została wspomniana na początku opracowania w przypadku strony internetowej iuscanonicum.it, na której odpowiedzi szczegółowe zostały zamieszczone jako noty wyjaśniające.
} 
internetowej. Ponadto ta sama odpowiedź na stronie iuscanonicum.it podana została jako nota wyjaśniająca. Przyglądając się obu rodzajom dokumentów nie trudno dostrzec, że zewnętrzna forma udzielonej odpowiedzi szczegółowej wykazuje duże podobieństwo do noty wyjaśniającej, co może stać się przyczyną potraktowania tego samego dokumentu jako noty lub odpowiedzi szczegółowej. Nie powinno się to jednak zdarzyć w omawianej sytuacji, gdyż strona iuscanonicum.it odwołuje się do oficjalnej strony Konferencji Episkopatu Włoch, gdzie ten sam dokument został podany jako odpowiedź szczegółowa. Rada nie posługuje się w nim sformułowaniem «nota», jak to zwykła czynić obecnie, ilekroć takie noty wydaje. Z drugiej strony brak przedstawienia w Profilu PRTP odniesienia do odpowiedzi szczegółowych może sugerować, że stanowią one jakąś specyficzną formę not wyjaśniających, skoro są odpowiedziami dotyczącymi kwestii szczegółowych, podobnie jak noty. Czym zatem jest owa «odpowiedź szczegółowa» (risposta particolare)?

Przyglądając się jedynie formie zewnętrznej not i odpowiedzi szczegółowych dostrzec można różnicę w formie adresowania, chociaż tak w jednym jak i drugim przypadku adresat nie został wyraźnie podany. Noty adresowane są w przeważającej liczbie (nie zawsze) do rzymskich dykasterii, a za ich pośrednictwem do poszczególnych podmiotów. Odpowiedzi szczegółowe w nagłówku zawierają odniesienie do adresata indywidualnego, aczkolwiek nie podanego $\mathrm{z}$ imienia i nazwiska. Występują zwroty takie jak: Dear Msgr., Eminenza Reverendissima, Reverendissimo Monsignore. Adresat określony jest indywidualnie, co podkreśla, że odpowiedź skierowana jest na pierwszym miejscu do niego samego i odnosi się do konkretnego problemu, co do rozwiązania którego nie ma on pewności. Sposób redagowania i adresowania odpowiedzi wskazuje, że procedura dotycząca wyjaśnienia pomija pośrednictwo innych dykasterii.

Potwierdzeniem tego jest również brak publikacji niektórych odpowiedzi na stronie PRTP oraz zamieszczenie ich jedynie na stronie Konferencji Biskupów czy Kościoła partykularnego, którego dana odpowiedź dotyczy. Wskazuje to na charakterystyczny dla odpowiedzi element konkretności, który może odnosić się tak do sytuacji, w której 
znajduje się adresat odpowiedzi, jak i samego jej przedmiotu. Poprzez publikację odpowiedzi Konferencja wskazuje, że jest ona punktem odwołania dla wszystkich Kościołów partykularnych znajdujących się na jej terenie, w których realizuje się taka podobna sytuacja.

Pomiędzy notą a odpowiedzią istnieją różnice formalne, które wynikają z celu wydania obydwu dokumentów. Nota przyjmuje charakter generalny, odpowiedź natomiast indywidualny. W formie wewnętrznej obydwa dokumenty pozostają jednak odpowiedziami. Różni je skala zasięgu. Decyzja Rady o publikacji indywidualnych odpowiedzi pozwala domniemywać, że zależy jej, by także inne Kościoły partykularne miały gotowe wyjaśnienie, które wyeliminuje ewentualne wątpliwości.

Wnioski wypływające $\mathrm{z}$ analizy poszczególnych odpowiedzi potwierdza PRTP charakteryzując na swojej stronie internetowej to, czym one są i w jakim celu są publikowane. Nie posiadają formalnej wartości odpowiedzi autentycznych, lecz są wynikiem pogłębionego studium nad zagadnieniem, które zostało przedstawione. Jednocześnie ukazują stanowisko Rady w odniesieniu do wyjaśnianego argumentu w sensie przewidzianym w kan. 19 KPK. Publikacja odpowiedzi podkreśla stanowisko Rady, które nabiera ogólnego znaczenia wykraczającego poza sytuację konkretną i indywidualną.

Treść prośby skierowanej do Rady oraz jej odpowiedź konkretnemu adresatowi dają podstawę do przekonania, że odpowiedzi partykularne stanowią wyjaśnienia bardziej o charakterze porad dotyczących stosowania prawa niż opinii czy ekspertyz.

W świetle powyższych uwag należy uznać za błędne zamieszczenie na stronie internetowej iuscanonicum.it dwóch dokumentów PRTP $^{53}$ jako not wyjaśniających. Mają one charakter szczegółowych odpowiedzi, gdyż kwestie w nich wyjaśniane dotyczą jedynie sytuacji kościelnej, która istnieje we Włoszech ${ }^{54}$.

\footnotetext{
53 Prot. N. 15157/2015; N. 15201/2015.

54 Treść tych dwóch odpowiedzi będzie przedmiotem rozważań w ostatnim rozdziale.
} 
Dotychczas wydane przez PRTP odpowiedzi szczegółowe dotyczą poniżej wyszczególnionych i omówionych kwestii.

a) Proces skrócony (processus brevior). Pierwsze dwie odpowiedzi PRTP zostały udzielone tego samego dnia (1.10.2015). Jedna z nich dotyczy wyjaśnienia i odpowiedzi na pytanie dotyczące możliwości przejścia $\mathrm{z}$ formalnego procesu o stwierdzenie nieważności małżeństwa na proces skrócony ${ }^{55}$. Powyższa wątpliwość mogła zaistnieć, gdyż w MI istnieją jedynie przepisy, które pozwalają wikariuszowi sądowemu, po zapoznaniu się ze skargą powodową w celu rozpoczęcia procesu zwykłego, na podjęcie decyzji o prowadzeniu go przed biskupem zgodnie z normami procesu skróconego. Nie ma natomiast przepisów, które regulowałyby możliwość przejścia z procesu zwykłego na skrócony w innej jego fazie po rozpoczęciu instancji.

Rada odpowiadając na pytanie i wyjaśniając nie tyle wątpliwość co raczej ewentualną możliwość przejścia $\mathrm{z}$ jednej formy procesu na drugą odwołała się do reguły inferencyjnej (wnioskowania) per analogiam legis zgodnie z zasadą ubi eadem legis ratio ibi eadem legis dispositio. Chodzi bowiem o sytuację, w której istnieje uregulowany stan prawny dotyczący zasad postępowania oraz drugi równie istotny, ale pozbawiony regulacji. Uregulowany stan prawny dotyczy możliwości przejścia z procesu zwykłego do procesu o dyspensę super rato „ilekroć podczas instrukcji sprawy wyłoni się bardzo prawdopodobna wątpliwość, że małżeństwo nie zostało dopełnione” (kan. $1678 \$ 4$ ). Nieuregulowany dotyczy możliwości przejścia z procesu zwykłego do skróconego. PRTP wyjaśniła, iż istnieje możliwość zawieszenia procesu zwykłego oraz zwrócenia się do stron z pytaniem o zgodę na instrukcję sprawy zgodnie $z$ normami procesu skróconego. Istnieje również możliwość „zamiany” procesu zwykłego na skrócony zanim sędzia wyda dekret ustanawiający formułę sporu i powołujący kolegium sędziowskie. Podobieństwo stanów prawnych (proces zwykły w jednym i drugim przypadku) pozwoliło na wyprowadzenie

55 Prot. N. 15138/2015. 
wniosku dotyczącego podobieństwa ich konsekwencji prawnych $\mathrm{w}$ oparciu o podobną ratio legis obydwu przypadków ${ }^{56}$.

W przypadku możliwości rozpoczęcia procesu skróconego muszą się weryfikować jednocześnie warunki sine qua non, o których w kan. 1683 i w art. 15 ZP dołączonych do norm kodeksowych w MI. Zgodnie z nimi strony muszą wyrazić publicznie i nieodwołalnie wolę dotyczącą rozpoznania skargi w procesie skróconym.

W zastosowaniu wnioskowania a simili (per analogiam legis) należy wziąć również po uwagę moment graniczny (ad quaem), do którego można zdecydować się na przejście z procesu zwykłego na skrócony. Wynika on nie tyle z samej normy zawartej w kan. 1678 $\$ 1$, ale z samej natury dwóch dróg procesowych. Tym momentem jest zakończenie instrukcji. Moim zdaniem stwierdzenie dotyczące możliwości przejścia „podczas instrukcji sprawy” jest zbyteczne. Zamknięcie bowiem instrukcji sprawy wiąże się z całkowicie inną procedurą następującą w przypadku dyspensy super rato, procesu zwykłego i skróconego. Wchodzi się bowiem w fazę decyzyjną procesu, a ta ze swej natury powinna prowadzić do podjęcia jednoznacznej decyzji.

Druga sytuacja dotycząca procesu skróconego odnosi się do wyjaśnienia wstępnych wymagań jako warunku rozpoczęcia procesu skróconego, o których mowa w kan. 1683 i art. 15 ZP $\mathrm{P}^{57}$. Zgodnie z tymi normami proces skrócony nie może się rozpocząć, jeśli: 1) żądanie nie zostało zgłoszone przez obydwoje małżonków; 2) lub przez jednego $\mathrm{z}$ nich za zgodą drugiego. Podane wymagania są warunkiem sine qua non rozpoczęcia każdego procesu przed biskupem. Uprzednia zgoda obu stron odpowiada bowiem naturze procesu skróconego, w którym zgodne współdziałanie stron wychodzi naprzeciw wymogowi szybkości procesowej. Ponadto zgoda ta jest wymagana, gdyż proces skrócony jest wyjątkiem od normy ogólnej, która reguluje sposób postępowania na drodze procesu zwykłego.

\footnotetext{
56 J. Stelmach, Kodeks argumentacyjny dla prawników, Zakamycze 2003, ss. 72-73.

57 Prot. N. 15139/2015. Ten sam problem został wyjaśniony tymi samymi słowami we wcześniejszej odpowiedzi PRTP: Prot. N. 15138/2015.
} 
Prośba o wyjaśnienie skierowana do Rady zrodziła się w oparciu o analogię z art. $11 \$ 2 \mathrm{ZP}$, w którym czytamy, że zgoda współmałżonka, jeśli skarga powodowa podpisana jest przez jednego $\mathrm{z}$ nich oznacza, że „strona pozwana nie sprzeciwia się żądaniu, jeżeli zdaje się na sprawiedliwość sądu lub prawidłowo wezwana po raz drugi, nie udziela odpowiedzi" ${ }^{58}$. Kwestia wymagająca wyjaśnienia odnosiła się do możliwości odniesienia takiego sformułowania do procesu skróconego. Chodziło o to, czy strona, która została prawidłowo wezwana po raz drugi lub zdaje się na sprawiedliwość sądu, może być uznana za wyrażającą zgodę na prowadzenie sprawy na drodze procesu skróconego.

Rada odpowiedziała, że norma zawarta w art. $11 \$ 2$ dotycząca domniemanej zgody przy braku odpowiedzi odnosi się jedynie do procesu zwykłego. Nie można jej stosować do procesu skróconego. Zgoda współmałżonka wymagana do rozpoczęcia procesu skróconego może być wyrażona w różny sposób, zawsze jednak tak, by gwarantowała publicznie i nieodwołalnie jego wolę oraz chroniła sędziego i drugą stronę. Rada udzielając wyjaśnienia nie odwołała się do wnioskowania a simili. W analizowanej kwestii nie mamy do czynienia $\mathrm{z}$ dwiema sytuacjami, w których realizuje się podobieństwo stanów prawnych (proces zwykły w jednym i drugim przypadku). Proces skrócony jest wyjątkiem od procesu zwykłego i należy zastosować wnioskowanie, które będzie odróżniało regułę od wyjątku od niej, to co szczegółowe od tego, co ogólne zgodnie z zasadą lex generalis non derogat legi speciali.

b) Najstarszy sufragan. Kwestia najstarszego sufragana dotyczy również procesu skróconego. Odnosi się ona do apelacji od wyroku stwierdzającego nieważność małżeństwa wydanego przez biskupa, przed którym proces był prowadzony ${ }^{59}$. Zgodnie z kan. $1687 \$ 3$ od wyroku wydanego przez metropolite , przysługuje apelacja do najstarszego sufragana”. Wątpliwość, z którą zwrócono się do Rady dotyczyła określenia najstarszego sufragana: czy jest nim sufragan najstarszy

$58 \mathrm{ZP}$, art. $11 \$ 2$.

59 Prot. N. 15155/2015. 
wiekiem czy sufragan najdłużej spośród wszystkich pozostałych sprawujący swój urząd?

W odpowiedzi Rada podkreśla, że pojęcie najstarszego sufragana występuje w Kodeksie w kilku kanonach ${ }^{60}$. Jest ono jednak w nich dookreślone wskazując wyraźnie, że chodzi o sufragana najstarszego promocją (promotione antiquior). Rada zauważa, że takiego dookreślenia najstarszego sufragana brakuje w MI. Jej zdaniem, należy uznać, że w MI nie chodzi ani o sufragana najstarszego wiekiem, ani najstarszego promocją, lecz tego, który sprawuje urząd w najstarszej ze wszystkich diecezji sufragalnych wchodzących w skład metropolii.

Czym zatem kierowała się PRTP wydając takie wyjaśnienie, które raczej odbiega od powszechnie przyjętych określeń nie tylko najstarszego sufragana, lecz również najstarszego kardynała ${ }^{61}$ ? Pomimo braku odniesienia do czasu promocji kardynalskiej, starszeństwo pośród kardynałów, zgodnie z tradycją i normami poprzedniego kodeksu $^{62}$, mierzone jest również obecnie stażem w Kolegium Kardynalskim. PRTP w swoim uzasadnieniu pominęła jednak tę tradycję. Również brak kodeksowych odniesień do dookreśleń starszeństwa kardynałów nie wpłynął na jej interpretację starszeństwa sufraganów.

Uzasadniając swoją opinię Rada zastosowała następujące wnioskowanie. Określenie starszeństwa pośród sufraganów poprzez wyraźne odwołanie się do ich promocji na ten urząd dotyczy pewnych zadań uzupełniających, które ci spełniają w określonych i raczej rzadkich sytuacjach. Natomiast apelacja od wyroku biskupa może weryfikować się znacznie częściej. Rada odwołuje się zatem do innych wartości i dyrektyw. Wartością procesową, która wysuwa się na pierwsze miejsce jest jakość prawa, które gwarantuje stałość i pewność podejmowanych przez podmioty działań i jednocześnie stałe miejsce ich odniesienia. Można przewidzieć, że uzależnienie starszeństwa sufragana od jego wieku czy promocji na urząd wiąże się z organizacją i przenoszeniem trybunału apelacyjnego przy każdorazowej zmianie starszeństwa.

${ }^{60} \mathrm{KPK}$, kann. $421 \S 2,425 \$ 3,501 \S 3$.

61 KPK, kann. $352 \S 2,355 \$ 1$.

${ }^{62}$ KPK 1917, kan. 237. W kan. zostało użyte sformułowanie «antiquior promotione». 
Trybunał apelacyjny powinien być stały, jednoznacznie i pewnie określony i nie narażony na nieustanne zmiany. Wartość, na jaką Rada zwróciła uwagę, wyraża się w treści zasady prawa w jej sensie dyrektywalnym, której konsekwencją jest norma zawarta w kan. 1438 , zwłaszcza w punkcie $2^{63}$. Zasady prawa stanowią szersze kryterium interpretacyjne ${ }^{64}$. Norma zawarta w tym kanonie zobowiązuje metropolitę do wyznaczenia na stałe za zgodą Stolicy Apostolskiej trybunału apelacyjnego dla spraw rozpatrywanych wobec niego. $\mathrm{Na}$ podstawie tej zasady Rada stwierdza, że jej zdaniem należy z powyższego wyciągnąć wniosek, że stałość trybunału gwarantowana jest przez jednoznaczne określenie niezmiennego jego miejsca. Wyklucza to interpretację zwrotu «najstarszy sufragan» w kontekście jego zmienności uzależnionej od wieku czy promocji na urząd. Najstarszym sufraganem jest biskup najstarszej diecezji sufragalnej należącej do metropolii.

Wyjaśnienie podane przez Radę skłania do refleksji. Po pierwsze, jeśli Rada odwołuje się do pewności prawa, a reguły interpretacyjne nie zawsze są pomocne dla zrozumienia tekstu prawnego, to tekst powinien być pisany jednoznacznie i pewnie. Zamiast sformułowania «najstarszy sufragan» można użyć sformułowań bardziej precyzyjnych, jak np.: «trybunał najstarszej sufraganii», czy «trybunał ustanowiony zgodnie z kan. $1438,2^{\circ} »$. Druga możliwość wydaje się bardziej precyzyjna, gdyż metropolita decyduje jednoznacznie. W pierwszym przypadku może dojść do sytuacji, gdy diecezje sufragalne powstaną w tym samym czasie, tworząc metropolię. Jeśli istniały wcześniej i należały do innych metropolii, to czy ich starszeństwo można mierzyć datą ich utworzenia jako diecezji, skoro w nowej metropolii zaistniały jako diecezje sufragalne w jednym momencie?

c) Proces dokumentalny a dochodzenie wstępne dotyczące stanu wolnego osób. Kolejna prośba, z którą się zwrócono do PRTP dotyczyła obowiązywalności interpretacji autentycznej kan. 1686 (obecnie

\footnotetext{
${ }^{63}$ W tekście odpowiedzi Rada cytuje $\$ 2$ kan. 1438. Niestety, pojawiła się tu pomyłka. Jednostką podziału kanonu nie są paragrafy $(\$)$, lecz punkty $\left({ }^{0}\right)$.

64 KPK, kan. 19.
} 
kan. 1688) dokonanej przez Radę oraz odpowiedzi, jakiej udzieliła Sygnatura Apostolska w tej samej materii ${ }^{65}$. Wątpliwość prawna, która się zrodziła i wymagała interpretacji autentycznej brzmiała następująco: „Czy w celu udowodnienia stanu wolnego osób, które, mimo że są związane formą kanoniczną podjęły próbę zawarcia związku małżeńskiego przed urzędnikiem stanu cywilnego lub szafarzem niekatolickim, wymagany jest koniecznie proces na podstawie dokumentów omówiony w kan. 1686, czy też wystarczy badanie przedmałżeńskie opisane w kan. 1066-1067? Rada odpowiedziała negatywnie do pierwszej części pytania i pozytywnie do drugiej ${ }^{66}$.

Obecna wątpliwość dotyczyła obowiązywalności interpretacji autentycznej w odniesieniu do kan. 1688 dotyczącego przeprowadzenia procesu opartego na dokumentach. Rada odpowiedziała, że nowy kanon nie wnosi żadnych znaczących zmian w stosunku do tego, co zostało zawarte $\mathrm{w}$ poprzednio obowiązującym kan. 1686. Zmiany dotyczą wprowadzenia w kan. 1688 osoby biskupa diecezjalnego, który obok wikariusza sądowego lub wyznaczonego sędziego może orzec nieważność małżeństwa na podstawie dokumentów. Druga zmiana dotyczyła kanonu, a właściwie jego treści, do którego odwołuje się obowiązujący kan. 1688. Jest nim kan. 1676 zastępujący wcześniej obowiązujący kan. 1677, który wraz z wejściem w życie nowych przepisów przestał obowiązywać. Po wnikliwej analizie treści przepisów Rada uznała, że elementy, które znajdowały się u podstaw wcześniej dokonanej interpretacji pozostają niezmienne i z tego powodu uważa, że nie jest konieczna żadna nowa interpretacja autentyczna.

d) III instancja. Do PRTP wpłynęło zapytanie dotyczące możliwości apelacji do trzeciej instancji, tj. Roty Rzymskiej w sytuacji,

\footnotetext{
65 Supremum Signaturae Apostolicae Tribunal, Quaesitum. Responsio in re particulari de investigatione praevia ad matrimonium celebrandum, Periodica 97 (2008), ss. 45-46.

66 AAS 76 (1984), s. 746-747.
} 
w której w pierwszej instancji orzeczono nieważność małżeństwa, a druga instancja opowiedziała się za jego ważnością ${ }^{67}$.

W przypadku odpowiedzi szczegółowych, inaczej niż w przypadku not wyjaśniających i deklaracji, Rada nie podaje argumentacji, która znajdowała się u podstaw skierowanego do niej pytania, ani nie analizuje sytuacji, która wymagałaby jej stanowczego oświadczenia i wydania opinii. Nieznana jest racja, która przemawiała za skierowaniem pytania dotyczącego możliwości odwołania się do III instancji w sytuacji dwóch sprzecznych wyroków (I instancja pro nulitate, II instancja pro validitate). Racji takich można się zatem jedynie domyślać. Dotyczą one ilości apelacji, które mogą zostać wniesione według nowych norm wprowadzonych przez MI.

W MI została unormowana jedynie sytuacja odnosząca się do możliwości odwołania się do trybunału III stopnia w celu nowego wniesienia sprawy, o ile wyrok stał się wykonalny, czyli za nieważnością małżeństwa, po dwóch zgodnych orzeczeniach sądów I i II instancji ${ }^{68}$.

Według obowiązujących przepisów wyrok stwierdzający nieważność w trybunale I stopnia staje się wykonalny, jeśli po powiadomieniu o nim stron żadna $\mathrm{z}$ nich nie wnosi w terminach ustawowych apelacji, która posiada skutek zawieszający ${ }^{69}$. Skutkiem wykonalności wyroku jest możliwość zawarcia przez strony nowego małżeństwa, „chyba że zostało to zabronione zakazem dołączonym do samego wyroku lub postanowieniem ordynariusza miejsca"70.

Nowe przepisy kodeksowe normują sytuację, w której wykonalność została zawieszona z powodu apelacji do II instancji. Wydany w II instancji wyrok potwierdzający wyrok I instancji za nieważnością małżeństwa skutkuje jego wykonalnością. Pojawia się jednak pytanie, czy wykonalność wyroku została zasądzona na podstawie wyroku

\footnotetext{
67 Prot. N. 15264/2015. W treści odpowiedzi pojawił się kan. $1683 \$ 3$, na który powołuje się Rada. Takiej jednostki redakcyjnej nie było w Kodeksie przed 8.12.2015 r. oraz nie ma jej po wejściu w życie nowych przepisów.

${ }^{68} \mathrm{KPK}, \mathrm{kan} .1681$.

${ }^{69}$ KPK, kan. 1638, $1680 \S 1$.

70 KPK, kan. $1682 \S 1$.
} 
II instancji, czy ta jedynie potwierdza wykonalność po I instancji? Podstawą takiego sposobu myślenia i pojawiającej się wątpliwości jest rezygnacja przez papieża Franciszka z dotychczas obowiązującej zasady sententia duplex conformis. Wątpliwość może pojawić się w związku z nowym sformułowaniem w kan. 1681. Zgodnie z normą w nim zawartą, jedynie wyrok podlegający wykonaniu umożliwia wniesienie sprawy do III instancji. W kanonie został pominięty całkowicie dekret II instancji potwierdzający wyrok I instancji, o którym mowa w kan. $1680 \$ 2$. W przypadku zatem potwierdzenia wyroku I instancji jedynie dekretem, wniesienie sprawy do III instancji w oparciu o nowe i poważne argumenty dotyczyłoby wyroku I instancji. Dekret II instancji nie zastępuje w takiej sytuacji wyroku I instancji, przeciwko któremu wnosi się sprawę do III instancji.

Wydaje się jednak, że takie ujęcie sprawy jest błędem legislacyjnym i należałoby się odwoływać do art. $290 \$ 2$ Instrukcji Dignitas connubii (dalej DC), który dotyczy wyroku I instancji potwierdzonego także dekretem. Taka interpretacja podparta jest sformułowaniem $\mathrm{z}$ kan. $1680 \$ 2$, w którym dekret jest czymś więcej niż jedynie elementem o charakterze proceduralnym, skoro potwierdza wyrok ${ }^{71}$.

Wskazówką pozwalającą na rozwiązanie powyższej kwestii jest wyjaśnienie z kan. $1682 \$ 1$, zgodnie z którym pierwszy wyrok (sententia) stwierdzający nieważność, a nie orzeczenie (pronuntiatio) jest wyrokiem wykonalnym zgodnie z zasadą, że jeden wyrok stwierdzający nieważność małżeństwa staje się wyrokiem wykonalnym. Wyjaśnia to papież Franciszek przedstawiając założenia zamieszczone na początku MI, które przyświecały dziełu reformy procesu o stwierdzenie nieważności małżeństwa. W założeniu nr I stwierdza wyraźnie, że jeden wyrok stwierdzający nieważność małżeństwa podlega wykonaniu, chyba że złożona od niego apelacja zawiesza wykonalność. Papież nie precyzuje, czy chodzi tu o wyrok I instancji, czy o wyrok II instancji. Rezygnacja z zasady dwóch zgodnych wyroków

71 P. Skonieczny, Komentarz do art. 4 MI, w: P. Skonieczny (red.), Praktyczny komentarz do Listu apostolskiego motu proprio Mitis Iudex Dominus Iesus papieża Franciszka, dz. cyt., s. 148. 
(„wydawało się stosowne..., aby... nie były już wymagane dwa zgodne wyroki stwierdzające nieważność, ale wystarczała moralna pewność osiągnięta przez pierwszego sędziego zgodnie z przepisami prawa”) skutkuje wykonalnością wyroku na jakimkolwiek stopniu orzekania.

Inna sytuacja, która stała się przedmiotem zapytania, weryfikuje się w przypadku wyroku pozytywnego w I instancji i negatywnego w II. Negatywny wyrok powoduje konieczność powrotu do zasady podwójnej sentencji zgodnej. Może zrodzić się pytanie, czy zatem odwołanie się do III instancji nie stoi w sprzeczności z zasadą jednoinstancyjności przy pozytywnym wyroku i czy można w tej sytuacji zwrócić się do trybunału III stopnia. Dodatkowo jest to pytanie dotyczące jednej czy dwóch możliwości apelacji.

Odpowiedź PRTP jest jednoznaczna. Rada stwierdza, że dotychczasowa dyscyplina zwracania się do trybunału III instancji, którym jest Rota Rzymska, została potwierdzona przez papieża Franciszka w MI. Powołuje się przy tym na nieistniejący ani przed ani po wejściu w życie MI kan. $1683 \S 3$ (?), według którego Rota Rzymska pozostaje Trybunałem III instancji dla całego Kościoła ${ }^{72}$. Racją bardziej uzasadniającą niż to wadliwe odwołanie jest zastosowanie normy stanowiącej, że sprawy dotyczące stanu osób nigdy nie przechodzą w stan rzeczy osądzonej ${ }^{73}$.

Jednocześnie odpowiedź Rady rozwiązuje kwestię dotyczącą ilości możliwych apelacji (jedna czy dwie?). Za możliwością jednej apelacji przemawia rezygnacja $\mathrm{z}$ zasady duplex conformis oraz brak wyraźnych unormowań w MI przyznających wprost stronie pokrzywdzonej (wyrokiem negatywnym) prawo do kolejnej apelacji1 ${ }^{74}$. Za podwójną apelacją przemawia zasada dotycząca stanu osób, który nie przechodzi w stan rzeczy osądzonej, jak również tradycja kanoniczna, do której nawiązuje kan. $1680 \$ 1$ podkreślając poczucie krzywdy wyrządzone wyrokiem pozytywnym (gravamen). Taka właśnie sytuacja weryfikuje

\footnotetext{
72 O tym w kan. $1444 \$ 1,2^{0}$ oraz w nr. VII założeń przyświecających reformie procesu małżeńskiego.

${ }^{73}$ KPK, kan. 1643.

74 Istniejące w kan. $1680 \$ 1$ sformułowanie ujmuje ogólnie prawo do apelacji.
} 
się w przypadku wyroku pozytywnego w I instancji i negatywnego w II instancji. Za takim rozwiązaniem przemawiają również racje wykładni językowej, systemowej, historycznej czy komparatystycznej ${ }^{75}$.

Strony mogą jednak prosić, aby trybunał III instancji ze względu na słuszne i racjonalne przyczyny został wyznaczony przez Sygnaturę Apostolską blisko miejsca zamieszkania stron. Przychylne rozpatrzenie prośby wynika $\mathrm{z}$ założeń nowego procesu, umożliwiających stronom łatwiejszy dostęp do trybunałów oraz zaangażowanie się biskupa w sprawy sądowe.

\section{Casus włoski}

Ostatnia odpowiedź szczegółowa PRTP (18.11.2015), która została zamieszczona na jej stronie internetowej dotyczy specyficznej organizacji trybunałów we Włoszech i ich funkcjonowania w związku z wejściem w życie przepisów $\mathrm{MI}^{76}$. Tym problemem Rada zajęła się już wcześniej (13.10.2015). Druga odpowiedź dotyczyła zakresowo i przedmiotowo tej samej materii ${ }^{77}$. Nie została ona zamieszczona na stronie internetowej Rady. Można ją odnaleźć na stronie Konferencji Episkopatu Włoch. Sytuację taką nie jest trudno wyjaśnić, gdyż wcześniejsza odpowiedź dotyczyła specyfiki organizacji trybunałów kościelnych w sprawach o stwierdzenie nieważności małżeństwa we Włoszech, która została unormowana w Motu proprio Qua cura wydanym przez papieża Piusa XI w 1938 r. ${ }^{78}$ Późniejsza odpowiedź opublikowana na stronie internetowej Rady - na co wskazuje dokument Sygnatury Apostolskiej, a zwłaszcza dołączona do niego opinia biegłego - dotyczy podobnej sytuacji, która istnieje w innych Kościołach partykularnych. Wcześniejszy dokument jej nie ujmował. Odnosił się jedynie do Kościoła włoskiego. Pierwsza czasowo odpowiedź Rady

\footnotetext{
75 Argumenty te przedstawia P. SKonieczny, Komentarz do art. 4 MI, art. cyt., ss. 133-134.

76 Prot. N. 15201/2015.

77 Prot. N. 15157/2015.

78 Pius XI, Qua cura, 8.12.1938, AAS 30 (1938), ss. 410-413.
} 
nie dotyczy zatem jedynie sytuacji, lecz również obowiązywalności Qua cura. Treścią drugiej odpowiedzi jest również sytuacja Kościołów partykularnych, które mają taką samą organizację trybunałów, jaka istnieje we Włoszech. Jest to racja stojąca za jego publikacją.

Pierwsza odpowiedź PRTP dotyczy obowiązywalności Qua cura w związku z wejściem w życie nowych przepisów odnoszących się do organizacji trybunałów kościelnych. Zwracający się do Rady Monsignore prosił o wyjaśnienie dotyczące aplikacji art. $8 \$ 2 \mathrm{ZP}$ w odniesieniu do tego, co ustanowił Pius XI w Qua cura. Zapytanie i odpowiedź pojawiły się przed wejściem w życie MI, co świadczy o trosce o prawidłowe zastosowanie nowych norm.

Sytuacja w Kościele włoskim, która wymagała wyjaśnienia, przedstawia się następująco. Na mocy Qua cura każdy Region kościelny składający się z metropolii, diecezji, tworzący strukturę Kościoła włoskiego (np. Lombardia, Piemont, Liguria, Apulia, Kalabria, Sycylia itd.), miał posiadać jeden wspólny trybunał kościelny orzekający w sprawach o stwierdzenie nieważności małżeństwa. Unormowanie dotyczące organizacji trybunałów odbiegało, na zasadzie wyjątku, od ogólnych zasad przewidzianych w KPK 1917 (sądy diecezjalne, metropolitalne i Stolicy Apostolskiej). Powyższa struktura organizacji Kościoła włoskiego została potwierdzona przez Kongregację Biskupów, która nadała im osobowość prawną zgodnie z kan. $433 \$ 2$ obowiązującego $\mathrm{KPK}^{79}$. Wątpliwość pojawiła się w konfrontacji dotychczas obowiązujących norm dotyczących jednego wspólnego trybunału dla wszystkich diecezji tworzących Region kościelny a normą zawartą w art. $8 \$ 2 \mathrm{ZP}$, która stanowi, że „biskup może wycofać się z trybunału międzydiecezjalnego". Nowe zasady są wyrazem woli papieża Franciszka jako prawodawcy, by każda diecezja miała własny trybunał do sądzenia spraw małżeńskich. Wierni mają tym samym łatwiejszy dostęp do sądu, co niejednokrotnie ma znaczący wpływ na podjęcie decyzji o rozpoczęciu procesu.

79 Kongregacja Biskupów, Decreta quibus unaquaeque regio ecclesiastica Italiae in personam moralem canonice erigitur, AAS 87 (1995), ss. 369-391. 
PRTP wyjaśniając zaistniałą sytuację czyni to odwołując się do ogólnych zasad dotyczących obowiązywania aktów normatywnych. Kan. 20 KPK stanowi, że „ustawa powszechna nie zmienia prawa partykularnego lub specjalnego, chyba że co innego jest w prawie wyraźnie zaznaczone"80. Wniosek wynikający z powyższej normy jest zatem jednoznaczny. Jeśli prawo powszechne, a takim jest MI, nie zastrzega, że deroguje motu proprio Qua cura, czego faktycznie nie czyni, oznacza, że dokument Piusa XI posiada nadal moc obowiązującą. Obowiązujące przepisy prawne pozostawałyby w sprzeczności $\mathrm{z}$ duchem reformy i papieskim zamysłem co do niej.

Drogą wyjścia ku realizacji nowych norm pozostaje jedynie dyspensa. Na mocy art. 124 PB może jej udzielić Sygnatura Apostolska. Taka prośba o dyspensę skierowana przez wszystkich biskupów diecezjalnych lub przynajmniej przez znaczną ich liczbę stawiałaby pod znakiem zapytania słuszność istnienia obowiązujących przepisów. Nie mają one racji istnienia, jeśli dostrzega się, że stoją w sprzeczności z duchem nowego prawa oraz jednocześnie zakłada się, że będą pojawiały się prośby o dyspensę od nich.

Wzbudzająca wątpliwości i prawdopodobnie kontrowersje powyższa sytuacja została zażegnana przez reskrypt papieski skierowany do dziekana Roty Rzymskiej na dzień przed wejściem w życie $\mathrm{MI}^{81}$. Franciszek postanawia, że wraz z wejściem w życie nowych norm dotyczących procesu małżeńskiego zostają abrogowane lub derogowane wszystkie normy przeciwne dotychczas obowiązujące, ogólne, partykularne, specjalne i ewentualnie zatwierdzone w formie specyficznej (jak np. motu proprio Qua cura). Reskrypt papieski w swoim sformułowaniu nie jest do końca zbyt precyzyjny. Nie jest wystarczająco jednoznaczne, czy deroguje Qua cura, czy jedynie podaje ten dokument jako przykład prawa partykularnego. Reskrypt papieski nie usunął wszelkich wątpliwości dotyczących obowiązywalności

\footnotetext{
80 Zgodnie z regułą kolizyjną: lex posterior generalis non derogat legi priori speciali.

81 FranciszeK, Rescritto ex audientia sulla riforma del processo matrimoniale introdotta dai due motuproprii pontifici del 15 agosto 2015, 7.12.2015, L'Osservatore Romano z 12.12.2015.
} 
zawartych w motu proprio Qua cura norm dotyczących Kościoła włoskiego. Potwierdzenia papieskiej intencji, zgodnie z założeniami przyświecającymi reformie, dokonała Rada w Liście skierowanym do sekretarza generalnego Konferencji Episkopatu Włoch ${ }^{82}$ oraz Sygnatura Apostolska ${ }^{83}$. Rada potwierdza w Liście, że motu proprio Qua cura zostało abrogowane. Sygnatura dołączając opinię biegłego wyjaśnia, że zawarte w reskrypcie papieskim przepisy „abrogują lub derogują przepisy przeciwne”, jak np. Qua cura. Przyczyną utraty obowiązywalności jest fakt ich sprzeczności z obowiązującymi przepisami. Abrogacja powoduje utratę mocy prawnej dokumentu Piusa XI w tym, co dotyczy zakazu powoływania trybunałów diecezjalnych w odniesieniu do rozpatrywania spraw o orzeczenie nieważności małżeństwa oraz nakazu organizowania trybunałów regionalnych w tej samej materii, wyłączając np. trybunały międzydiecezjalne dla kilku diecezji. W sprzeczności z nowymi normami pozostają te, które zakazują biskupowi diecezjalnymi wycofania się z trybunału regionalnego celem powołania trybunału diecezjalnego lub wraz z innymi biskupami diecezjalnymi trybunału międzydiecezjalnego. Nowe przepisy derogują tym samym w tym elemencie dotychczas obowiązujące.

Powyższe rozwiązanie stawia także w nowym świetle pytania dotyczące sposobu organizacji procesu skróconego przed biskupem, gdy ten nie może na razie zrezygnować z trybunału regionalnego. Nie wszyscy biskupi są w stanie zorganizować w swojej diecezji trybunał diecezjalny (zwłaszcza na terenach misyjnych) zapewniając właściwe jego funkcjonowanie. Ponadto abrogacja motu proprio nie jest równoznaczna $\mathrm{z}$ koniecznością likwidacji trybunałów regionalnych. Te mogą nadal istnieć ${ }^{84}$. Wątpliwość, biorąc pod uwagę nie tylko

\footnotetext{
82 Prot. N. 15247/2015, http://www.chiesacattolica.it/cci_new_v3/allegati/75928/ Lettera_PCTL_22.12.2015_risposta_a_\%20questioni_\%20aperte.pdf.

83 Prot. n. 51232/15 VAR, http://www.chiesacattolica.it/cci_new_v3/allegati/75928/ Lettera_Segnatura-Apostolica_22.12.2015_risposta_a_\%20questioni_\%20aperte. pdf.

84 Taka sytuacja weryfikuje się w przypadku trybunałów międzydiecezjalnych, których kompetencje rozciągają się na konkretny region (np. trybunały
} 
sytuację przed wejściem w życie MI, dotyczy przypadku, w którym proces ma być prowadzony przed biskupem zgodnie z kan. 1683-1687. Czy jest on zobowiązany do zorganizowania w tym celu trybunału? PRTP odpowiedziała, że biskup diecezjalny nie ma obowiązku ustanowienia trybunału, gdyż on sam jest w tym przypadku sędzią ${ }^{85}$. Obowiązkiem jego jest jednak skorzystanie z pomocy wikariusza sądowego ustanowionego na stałe (kan. $1420 \$ 1$ ), który przyjmuje skargę i wprowadza sprawę oraz obrońcy węzła małżeńskiego (kan. 1435-1436), którego udział w procesie jest obowiązkowy. W procesie bierze udział również instruktor i asesor. Oni jednak nie muszą być ustanowieni na stałe. Prawem stron jest jednak możliwość wniesienia sprawy w trybie skróconym do wikariusza sądowego jak również do przewodniczącego trybunału regionalnego, zwłaszcza gdy sprawa jest bardziej skomplikowana i brakuje zgody obu stron.

Nowy sposób unormowań procesu o stwierdzenie nieważności małżeństwa w Kościele łacińskim wprowadzony przez papieża Franciszka Listem apostolskim „Mitis Iudex Dominus Iesus” sprowokował pewne wątpliwości dotyczące aplikacji niektórych norm. Do tych wątpliwości odniosła się PRTP udzielając szczegółowych odpowiedzi na konkretne pytania. Rozwiewając wątpliwości sama nie ustrzegła się błędów w cytowaniu nieistniejących kanonów KPK lub błędnie przytaczając ich systematykę kodeksową.

międzydiecezjalne jako trybunały narodowe). Skoro te trybunały nie przestają istnieć, także w przypadku Włoch, reskrypt nie tyle abrogował (jak podaje PRTP w Liście) Qua cura, co derogował normy sprzeczne z obowiązującymi.

85 Prot. N. 15201/2015. Odpowiedź, inaczej niż odpowiedź wcześniejsza (15157/2015), została opublikowana, gdyż nie dotyczy jedynie sytuacji Kościoła włoskiego. W innych Kościołach partykularnych mogą bowiem również weryfikować się sytuacje organizacji Kościoła w oparciu o istniejące regiony. 
Pontifical Council for Legislative Texts with regard to doubts connected with the Apostolic Letter „Mitis Iudex Dominus Iesus”

\section{Summary}

The subject of the study is the analysis of the content of specific answers which were given by the Pontifical Council for Legislative Texts with regard to doubts which arose after the promulgation of the Apostolic Letter,,Mitis Iudex Dominus Iesus". Some of them were published on the website of the Council, others on the websites of Italian Bishops' Conference and other sites dedicated to canon law. Some answers were placed there as explanatory notes. Therefore, it was necessary to explain the difference between declarations, explanatory notes and specific answers to next comment on answers. 